\title{
IMPLEMENTASI NILAI-NILAI PANCASILA SEBAGAI IDEOLOGI DAN FALSAFAH BANGSA DI KEHIDUPAN SUKU ADAT TOBELO DALAM
}

\author{
Adriansyah Aria Kusumah, Alya Zahra Camila Muthmainnah, Salsazahra Rofilah, \& \\ Wiennetou Joel Hermesha \\ Institut Teknologi Bandung \\ Email: 10520081@mahasiswa.itb.ac.id
}

\begin{abstract}
Abstrak
Masyarakat Suku Tobelo Dalam adalah salah satu 300 kelompok etnik atau suku bangsa, atau tepatnya 1.340 suku bangsa di Indonesia yang masih terisolasi dari dunia luar. Dalam kehidupan kesehariannya suku Tobelo Dalam menganut nilai adat istiadat setempat yang sudah diwariskan secara turun temurun. Keberadaan Suku Tobelo Dalam yang diakui sebagai bagian dari masyarakat Negara Republik Indonesia, tentunya perlu menganut dan menanamkan nilai praksis Pancasila di kehidupan mereka karena Pancasila sebagai dasar negara berarti setiap tindakan Masyarakat dan Negara Indonesia harus sesuai dengan nilai-nilai Pancasila. Untuk mengetahui kehidupan, nilai-nilai kebudayaan, adat istiadat masyarakat, dan pengimplementasian nilai-nilai praksis Pancasila oleh Suku Tobelo Dalam maka dilakukan penelitian ini melalui metode studi pustaka dengan memperoleh berbagai data dan referensi literatur dari buku, jurnal ilmiah dan artikel media massa yang berkaitan dengan masalah untuk menguji hipotesis awal. Hasil penelitian menunjukan bahwa nilai dari adat istiadat Suku Tobelo Dalam sudah hampir sesuai dengan pengamalan nilai praksis pancasila, khususnya di bidang kemasyarakatan dan sitem kepemimpinan guna menciptakan kesejahteraan bersama Masyarakat Suku Tobelo Dalam. Akan tetapi dalam hal kepercayaan, sebagian besar dari mereka masih menganut kepercayaan leluhur dan masih sedikit yang menganut agama resmi sesuai dengan yang tercantum pada penjelasan pasal 1 UU Penodaan Agama. Namun pada Pasal 28E ayat (1) Undang- Undang Dasar Tahun 1945 tentang menjamin kebebasan beragama di Indonesia, bahwa kebebasan beragama dan kepercayaan tertentu yang dianut masyarakat di Indonesia termasuk salah satu hak asasi manusia yang sudah selayaknya dilindungi oleh negara dengan memastikan setiap masyarakatnya memeluk agama dan peribadatan dengan aman dan berjalan baik tanpa adanya interfensi dari luar.
\end{abstract}

Kata kunci: Adat Istiadat, Suku Tobelo Dalam, Nilai-nilai Praksis Pancasila.

\begin{abstract}
The Tobelo Dalam people are one of 300 ethnic groups or ethnic groups, or precisely 1,340 ethnic groups in Indonesia that are still isolated from the outside world. In their daily lives the Tobelo tribe in embracing the value of local customs that have been passed down through generations. The existence of the Tobelo Dalam tribe which is recognized as part of the society of the Republic of Indonesia, of course, needs to embrace and instill the praxis value of Pancasila in their lives because Pancasila as the basis of the state means that every action of the People and the State of Indonesia must be in accordance with the values of Pancasila. To find out the life, cultural values, customs of society, and the implementation of the praxis values of Pancasila by the Tobelo Tribe in this research through the method of literature studies by obtaining various data and reference literature from books, scientific journals and mass media articles related to the problem to test the initial hypothesis. The results showed that the value of the customs of the Tobelo Dalam tribe was almost in accordance with the practice of pancasila praxis values, especially in the field of community and leadership system to create prosperity with the Tobelo Dalam People. But in terms of beliefs, most of them still adhere to ancestral beliefs and there are still few who adhere to official religion in accordance with the explanation of article 1 of the Blasphemy Law. But in Article $28 E$ paragraph (1) of the 1945 Constitution on guaranteeing freedom of religion in Indonesia, that certain religious freedoms and beliefs embraced by the people in Indonesia include one of the human rights that should be protected by the state by ensuring that each of its people embraces religion and worship safely and runs well without any interference from outside.
\end{abstract}


Keywords: Customs, Tobelo Tribe In, Praxis Values of Pancasila.

\section{PENDAHULUAN}

Di zaman yang semakin maju dengan ilmu pengetahuan dan teknologi yang berkembang pesat, manusia terus bergerak maju demi kehidupan umat manusia yang semakin baik. Tanpa disadari, masih banyak orang-orang yang belum mampu mengikuti perkembangan zaman, khususnya mereka yang hidup di daerah pedalaman. Salah satunya adalah suku Tobelo Dalam.

Di tengah laut kemajemukan bumi nusantara ini, suku Tobelo Dalam adalah salah satu komunitas etnik yang masih memegang tradisi dan cenderung tertutup dengan dunia luar. Dampaknya, suku Tobelo Dalam mengalami ketertinggalan dalam pencapaian pemenuhan kebutuhan hidup manusia. Selain kondisi geografis yang sulit dijangkau, suku Tobelo Dalam memiliki relasi yang kurang baik dengan masyarakat umum.

Keberadaan komunitas adat terpencil seperti suku Tobelo Dalam ini merupakan realitas yang tidak bisa diabaikan di Indonesia. Dibutuhkan pembangunan berkelanjutan dalam segala aspek untuk meningkatkan taraf kehidupan dan kesejahteraan sosial. Artikel ini akan membahas bagaimana orang suku Tobelo Dalam beraktivitas dan bertahan hidup di era globalisasi ini. Tak hanya itu, artikel ini juga akan membahas korelasi antara perilaku suku Tobelo Dalam dan Pancasila, mengingat Pancasila adalah pedoman rakyat Indonesia dalam berkehidupan sehari-hari.

Muncul berbagai pertanyaan mengacu pada latar belakang, yaitu: bagaimana suku Tobelo Dalam dapat beradaptasi dengan lingkungan yang semakin modern? bagaimana korelasi kehidupan suku Tobelo Dalam secara umum dengan Pancasila? dan apa yang membuat suku Tobelo Dalam kesulitan mengikuti perkembangan zaman?

Tujuan dari pembuatan artikel ini adalah untuk mengetahui cara suku Tobelo Dalam beradaptasi dengan lingkungan yang semakin modern, untuk memahami hubungan kehidupan suku Tobelo Dalam dengan nilai-nilai Pancasila, dan untuk menganalisis kesulitan-kesulitan yang dialami suku Tobelo Dalam untuk mengikuti perkembangan zaman.

Manfaat yang didapatkan penulis dari artikel adalah pembaca dapat mengetahui kehidupan dan kebudayaan suku adat Tobelo Dalam serta kaitannya dengan implementasi nilai-nilai praksis Pancasila. Hipotesis awal dari penelitian adalah sebagian masyarakat Suku Adat Tobelo Dalam sudah mengamalkan nilainilai praksis Pancasila.

\section{METODE PENELITIAN}

Dalam penyusunan makalah ini, jenis penelitian yang digunakan adalah metode penelitian literatur tepatnya dengan metode studi kepustakaan. Menurut M. Nazir dalam bukunya yang berjudul "Metode Penelitian" menyatakan bahwa yang studi kepustakaan adalah teknik untuk mengumpulkan data dengan cara mengadakan penelaahan terhadap sumber data, baik berupa buku, literatur, catatan, dan laporan yang memiliki topik berkaitan dengan rumusan masalah yang ingin diselesaikan. Metode ini dipilih karena keterbatasan waktu dan tidak adanya kesempatan yang memungkinkan untuk dilakukan penelitian secara langsung kepada masyarakat Suku Tobelo Dalam. Dengan menggunakan metode studi kepustakaan diharapkan informasi yang didapatkan akan lebih relevan dengan realita yang terjasi dan data yang ingin diteliti lebih lanjut sebagai sumber data memiliki kredibilitas yang lebih tinggi.

Sifat dari penelitian ini adalah 
penelitian deskriptif. Sukmadinata (2006) menjelaskan bahwa penelitian dengan metode deskriptif adalah penelitian yang mengungkapkan secara spesifik bagi setiap masalah yang dibahas baik fenomena sosial maupun fenomena alam yang ada di dalam kehidupan masyarakat secara nyata. Dalam hal ini, spesifik berarti menyebutkan hubungan sebab-akibat serta penyelesaian dari masalah yang diangkat dalam kegiatan penelitian. Dengan menggunakan metode deskriptif, diharapkan penjelasan terhadap kehidupan suku Tobelo Dalam dan implementasi nilai-nilai Pancasila dalam kehidupan Suku Tobelo Dalam akan lebih sistematis.

Sumber data dalam penyusunan makalah ini adalah jurnal ilmiah, laporan peneliti mengenai perilaku dan tata cara hidup suku Tobelo Dalam, buku, publikasi pemerintah, dan situs berita serta artikel yang membahas mengenai suku Tobelo Dalam.

Metode pengumpulan data penelitian dilakukan oleh setiap anggota kelompok. Sumber data yang telah dikumpulkan kemudian saling dibagikan sehingga masing-masing anggota kelompok memiliki seluruh sumber data. Pengumpulan data dilakukan secara objektif. Data yang dikumpulkan diusahakan berjumlah sebanyak mungkin dan data yang digunakan memiliki kredibilitas yang tinggi.

Setelah semua data terkumpul, dilakukan pemeriksaan kembali atas kelengkapan data dan keselarasan data terhadap topik yang dibawakan. Setelah itu, dilakukan penyeleksian terhadap data yang sudah diperoleh. Kemudian, dilakukan analisis lanjutan terhadap masing-masing data yang diperoleh untuk menemukan implementasi nilai-nilai Pancasila terutama nilai praksis Pancasila dalam berbagai aspek kehidupan suku Tobelo Dalam.

Untuk melakukan analisis data penelitian, mula-mula dilakukan diskusi untuk menentukan hipotesis terhadap topik yang dibawakan. Kemudian dilakukan pengumpulan data yang membahas menganai Kehidupan Suku Tobelo Dalam. Setelah seluruh data terkumpul, dilakukan focus group discussion mengenai implementasi dari masing-masing nilai Pancasila pada kehidupan Suku Tobelo Dalam serta dilakukan pengecekkan ulang terhadap kredibilitas data yang sduah dikumpulkan. Setelah menyamakan sudut pandang dalam diskusi dan mendapatkan kesimpulan terhadap masalah, kemudian memulai penyusunan makalah.

\section{HASIL PENELITIAN DAN PEMBAHASAN Hasil Penelitian Adat Istiadat}

Adat istiadat merupakan kebiasaan turun temurun yang telah diikuti oleh masyarakat dalam jangka waktu yang panjang dan telah menjadi pedoman masyarakat secara keseluruhan. Menurut Kamus Besar Bahasa Indonesia (KBBI) arti dari kata adat istiadat merupakan tata kelakuan turun temurun yang terdapat di suatu masyarakat, bentuknya berupa warisan sehingga kuat integrasinya dengan pola perilaku masyarakat. Menurut (Koentjaraningrat, 2003:2) dalam (Nurgiansah, 2018) adat istiadat adalah kompleks konsep serta aturan yang mantap dan integrasi kuat dalam sistem budaya dari suatu kebudayaan yang menata tindakan manusia dalam kehidupan sosial kebudayaan itu.

Idealnya adat istiadat merupakan cerminan kepribadian dan jiwa suatu masyarakat tertentu. Ia mengatur berbagai macam aturan tata interaksi dan hubungan yang ada di suatu masyarakat. Nilai adat istiadat juga berperan sebagai alat untuk menjadikan hubungan suatu masyarakat tertib dan teratur, jika masing- masing yang ada di dalam masyarakat tentunya paham akan kedudukan nilai tersebut di 
kehidupan sehari-hari. Sebagaimana dikutip dari Pengantar Antropologi oleh Santri Sahar (2015) (Setyawati et al., 2021). Secara Historis suatu adat istiadat dalam masyarakat berbeda satu sama lain. Unsur-unsur yang terdapat dalam suatu adat istiadat menurut Buku Ajar Hukum Adat oleh Yulia (2016) (Dewi Sarah et al., 2021) adalah bahwa adanya tingkah laku yang dilakukan seseorang secara terus menerus, mempunyai dimensi waktu, dan mampu mempengaruhi lalu diikuti oleh orang lain.

Lalu pada Koentjaraningrat (2003) (Chilwanto et al., 2021) membagi secara terperinci pembagian adat-istiadat menjadi empat bagian khusus, yaitu:

a. Nilai-nilai budaya

Merupakan hasil pandangan bersama yang diwujudkan dalam kebiasaan yang dilakukan secara turun temurun Di Indonesia misalnya, gotong royong merupakan ciri khas kerja sama masyarakat Indonesia (Bella et al., 2021).

\section{b. Norma-norma}

Berperan sebagai aturan yang menjadi pedoman dari nilai suatu budaya. Setiap individu mengimplementasikan fungsi dan nilai dari norma yang ada di kehidupan bermasyarakat (Isnaini \& Dewi, 2021).

\section{c. Hukum}

Merupakan seperangkat aturan yang bersifat resmi, mengikat, mampu dilihat dan nyata. Hukum diimplementasikan di kehidupan bermasyarakat guna menciptakan suasana masyarakat yang tertib (Sofiyatul \& Dewi, 2021).

\section{d. Aturan khusus}

Aturan khusus adalah aturan yang mengatur aktivitas yang sangat jelas dan terbatas pada ruang lingkup kehidupan masyarakat (Hikmah \& Dewi, 2021).

\section{Suku Tobelo Dalam}

Hidup berburu meramu di belantara hutan Halmahera bagian utara, timur, hingga Halmahera bagian tengah. Masyarakat menyebut mereka dengan suku Togutil, yang artinya mereka yang terbelakang. Menurut Syaiful Madjid, peneliti sub etnis Tobelo ini mengatakan, terdapat dua kelompok dari komunitas etnis tersebut, yaitu Tobelo Dalam yang hidup didalam hutan dan Tobelo Luar yang hidup di luar hutan.

Sebenarnya, suku Tobelo Dalam ini lebih dikenal sebagai suku Togutil di masyarakat umum. Namun, orang Togutil sendiri tidak ingin dipanggil demikian dikarenakan Togutil bermakna konotatif yang artinya "terbelakang".

Menurut Sosebeko (2010) (Pertiwi \& Hidayah, 2021), asal usul Suku Tobelo Dalam adalah orang Portugis yang bersembunyi dari kejaran pasukan Kerajaan Ternate dan Alifuru. Mereka kemudian menyatu dengan masyarakat setempat, menghilangkan jejak sebagai orang Portugis dengan mempelajari bahasa Tobelo dan hidup berpindah- pindah ke daerah yang dianggap lebih aman.

Suku Tobelo Dalam sendiri tidak memiliki identitas diri sebagai Warga Negara Indonesia. Mereka bukannya tidak mau, hanya saja persyaratan administrasi menyulitkan mereka. Untuk mengurus KTP, mereka diwajibkan memiliki Kartu Keluarga yang tidak mereka miliki.

Meskipun mereka menolak beberapa ajaran agama dikarenakan bertentangan dengan adat istiadat, terdapat beberapa Masyarakat Suku Tobelo Dalam yang menganut agama Kristen. Suku Tobelo Dalam mulai meninggalkan aliran kepercayaan lokal semenjak tahun 1970-an.

\section{Kehidupan Suku Tobelo Dalam Pendidikan}

Pendidikan diakui secara luas 
memiliki peran penting dalam masyarakat. Oleh karena itu pendidikan semakin dikembangkan. Pendidikan dasar dan menengah baru mulai dipusatkan pada beberapa tahun terakhir. Namun, saat ini pendidikan lebih dikembangkan hingga pendidikan tinggi. Hal tersebut dilakukan karena pendidikan mampu memperbaiki status sosial seseorang atau kesejahteraan masyarakat itu sendiri. Tingkat pendidikan tertinggi Suku Tobelo Dalam adalah SMA yaitu sebanyak 6,5 persen, dan berdasarkan penelitiannya, sebanyak nilai persentase 43,5\% Suku Tobelo Dalam yang tidak sekolah atau sebanyak 20 keluarga, 14 kepala keluarga yang mengenyam Pendidikan sampai SD dengan nilai persentase $30.4 \%$, dan 9 kepala keluarga atau $19.6 \%$ sampai SMP (Sagaf, 2018).

Pemerintah Maluku Utara beberapa tahun terakhir baru saja membangun fasilitas sekolah di sebuah dusun yang berada di ibu Kecamatan yang jaraknya begitu jauh dari tempat Suku Tobelo Dalam berada, melihat kondisi pendidikan di kalangan Suku Tobelo Dalam, pemerintah mengharuskan anak-anak usia sekolah di Suku Tobelo Dalam menempuh Pendidikan (SLTP dan SLTA). Hambatan berupa jarak tempuh yang begitu jauh, tentu mempengaruhi minat sekolah pada anakanak di Suku Tobelo Dalam. Kondisi ini menunjukan bahwa rendahnya tingkat pendidikan ini karena awalnya mereka hidup dalam hutan rimba yang begitu jauh dari sentuhan pendidikan modern.

Berdasarkan Safrudi Sagaf dalam hasil wawancara tanggal 5 mei 2018, yang dikatakan salah seorang informan Dorlius Ngale-Ngale sebagai berikut: “Torang inigin torang pe ana-ana sekoloh supaya dorang jang sama deng torang cuman torang tara mampo, paling dorang kaluar SD abis itu so tara bisa lanjut" (Sagaf, 2018). Arti dari bahasa tersebut adalah: Kami ingin anak kami sekolah agar mereka jangan sama seperti kami lorang tua) akan tetapi kami tidak sanggup, mungkin mereka hanya lulus SD setelah itu tidak bisa melanjutkan sekolah lagi.

Menurut (Raharja \& Mandala, 2005). Salah satu investasi terpenting adalah pendidikan. Pendidikan dapat menunjang target masa depan yang akan dicapai, seperti pekerjaan yang layak dan kehidupan yang sejahtera.

\section{Sistem Perkawinan}

Masyarakat Suku Tobelo Dalam pada saat ini sudah lebih terbuka, dan mulai meninggalkan tradisi aslinya, oleh karena itu masyarakatnya tidak sedikit yang memilih untuk menikah dengan masyarakat luar Suku Tobelo Dalam. Berdasarkan penelitian, informan Dekelu Baikole menyebutkan bahwa sistem poligami tidak diperbolehkan di Suku Tobelo Dalam, karena sebagian masyarakat sudah mengenal agama dari luar (Sagaf, 2018).

\section{Ritual dan Sistem Kepercayaan}

Sistem kepercayaan Suku Tobelo Dalam yang tinggal di pemukiman Desa Dodaga, Dusun Tukur-Tukur, sebagian sudah menganut agama Kristen Protestan, mereka mulai meninggalkan kepercayaan leluhur sejak tahun 1970-an ketika masuknya penyebaran agama Kristen di daerah tersebut (Sagaf, 2018). Selain itu kondisi perpindahan Suku Tobelo Dalam ke agama Kristen Protestan juga didukung oleh adanya proyek pemukiman kembali masyarakat terasing pada tahun 1970-an. Berdasarkan informasi dari beberapa informasi setempat, masyarakat yang masih tinggal jauh di dalam hutan, khususnya yang masih belum mendapat pembinaan dari pemerintah maupun masyarakat luar, masih menganut sistem kepercayaan asli leluhur Suku Tobelo Dalam.

Sistem kepercayaan atau keyakinan asli Suku Tobelo Dalam terpusat pada ruh- 
ruh leluhur yang menempati di seluruh kawasan alam di lingkungan mereka tinggal dengan kekuasaan dan kekuatan tertinggi terpusat pada Jou Ma dutu, yaitu pemilik alam semesta atau biasanya disebut juga o gikiri-moi yaitu jiwa atau nyawa (Martodirdjo, 1996).

Penghormatan dan pemujaan pada leluhur yang merupakan kepercayaan yang sudah diwarisi secara turun temurun di kalangan Suku Tobelo Dalam. Masyarakat setempat percaya bahwa ruh-ruh tersebut mempunyai pengaruh yang besar dalam keseharian mereka.

\section{Interaksi Sosial Suku Adat Tobelo Dalam}

Suku Tobelo Dalam mempunyai tata cara, adat istiadat, bahasa serta normanorma yang berbeda dengan masyarakat pada umumnya (Sagaf, 2018) (Ulfah et al., 2021). Interaksi sosial di kalangan Masyarakat Suku Tobelo Dalam berjalan sangat baik yang dapat dilihat dari cara mereka saling membantu dan bekerja sama guna memenuhi kebutuhan mereka. Masyarakat Suku Tobelo Dalam juga berinteraksi dengan masyarakat luar dengan baik.

Seperti yang dikemukakan oleh salah satu responden Robi Gamu pada penelitian Safrudi Sagaf sebagai berikut sebagai berikut. "Tong sekarang itu hidup pake sistem kerja sama contohnya kalau kita tara ada makanan kita bisa pinjam tetanggapunya dulu, torang juga biasa baku buju pigi bahalo sagu popeda samasama, kalau deng orang-orang bukan torang biasanya nanti kalau tong pigi pasar, atau ada kerja bakti "(hasil wawancara pada tanggal 9 Mei 2018) (Sagaf, 2018). Arti dari perkataan tersebut adalah hidup kami sekarang itu kami menggunakan sistem kerja sama, contohnya ketika saya tidak memiliki makanan saya bisa meminjam punya tetangga, selain itu kami biasanya saling mengajak untuk pergi bersama-sama membuat sagu papeda.

Kerja sama merupakan faktor utama terjadinya interaksi sosial Suku Tobelo Dalam dengan masyarakat luar. Sebagaimana yang telah kita ketahui, bahwa sudah merupakan sifat alami manusia untuk saling membutuhkan satu sama lain (Susanty, 2015) (Febriyanti \& Dewi, 2021).

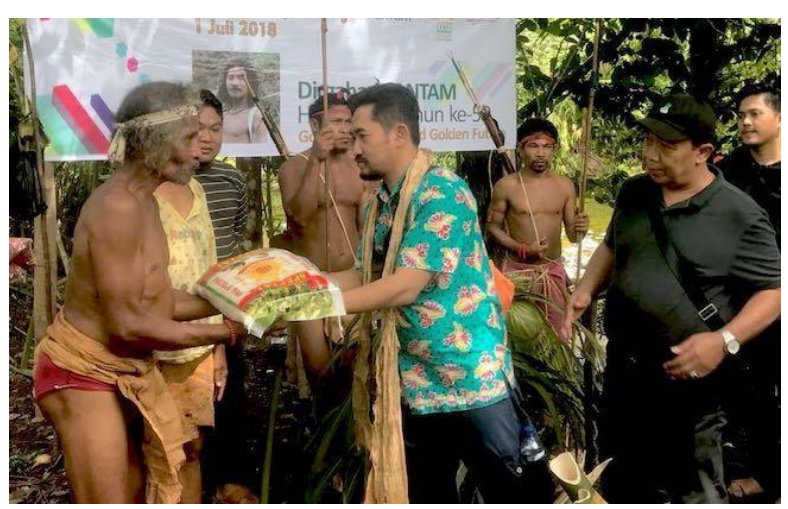

Gambar 1. Warga Tobelo Dalam Berinteraksi dengan Masyarakat Luar Sumber: Dok Kieraha.com

\section{Interaksi Suku Tobelo Dalam dengan} Alam

Keeratan hubungan Suku Tobelo Dalam dengan alam bisa dilihat dari keyakinan mereka bahwa hutan merupakan rumah dan sumber generasi baru mereka. Terdapat budaya yang dilakukan secara turun temurun yang dilakukan Suku Tobelo Dalam saat bayi lahir, maka salah satu anggota keluarga wajib menanam satu pohon, karena bagi mereka pohon dianggap sumber kelahiran generasi baru. Maka dari itu masyarakat Suku Tobelo Dalam sangat lekat kehidupannya dengan hutan, dan kebutuhan masyarakatnya tercukupi di dalamnya,walaupun pola hidup masyarakat Suku Tobelo Dalam sebagian masih banyak yang nomaden. 


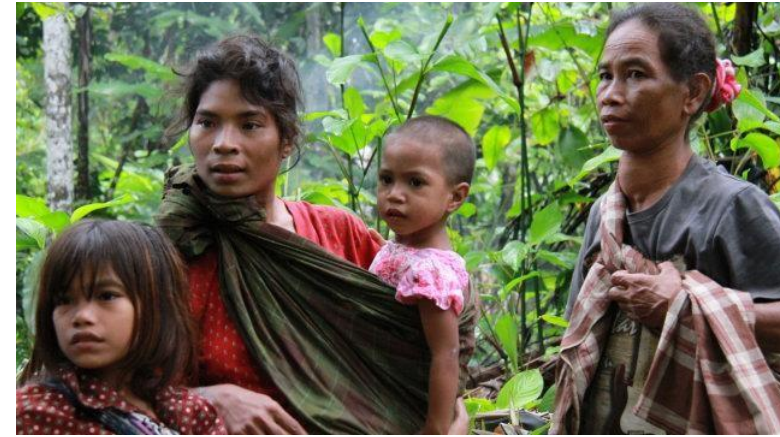

Gambar 2. Perempuan Tobelo Dalam di Hutan Halmahera

Sumber: Faris Bobero/Cermat

\section{Ekonomi Suku Tobelo Dalam Pekerjaan}

Pekerjaan yang dilakukan atau ditekuni Suku Tobelo Dalam pada saat ini yaitu meramu dan berburu, hampir keseluruhan masyarakat Suku Tobelo Dalam bekerja sebagai peramu dan pemburu, hanya sebagian kecil diantaranya yang bekerja sebagai petani. Pekerjaan merupakan suatu kegiatan yang wajib dilakukan oleh setiap kelompok orang demi kelangsungan hidupnya atau guna memenuhi berbagai macam kebutuhan-kebutuhan dalam hidupnya, terutama kebutuhan pokok. Manusia tentunya membutuhkan uang agar dapat memenuhi berbagai kebutuhan, umumnya uang merupakan hasil dari bekerja, dari berbagai jenis pekerjaan, Suku Tobelo Dalam mempunyai jenis pekerjaan yang dilakukan guna memenuhi kebutuhan kehidupan sehari-hari.

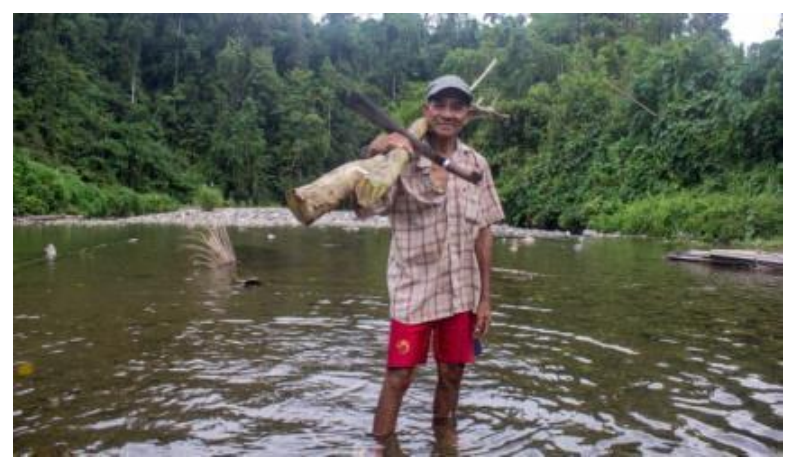

Gambar 3. Warga Tobelo Dalam Mengambil Kayu untuk Perapian di Dapur Sumber: Faris Bobero/Cermat

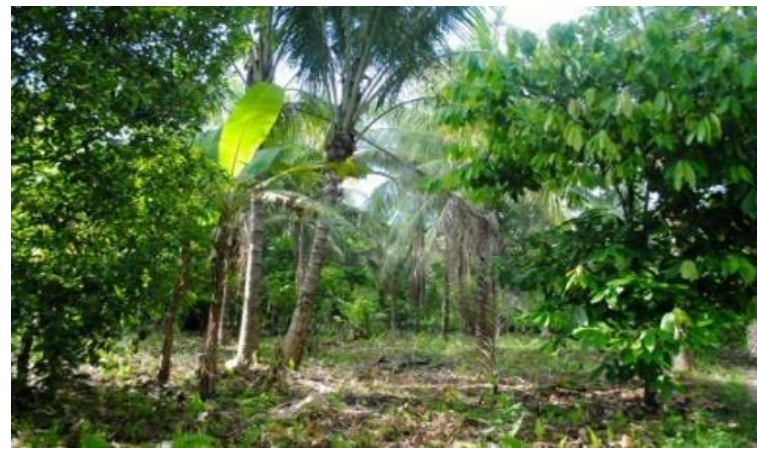

Gambar 4. Perkebunan Warga Tobelo Dalam yang Sudah Tinggal Menetap Sumber: M. Rahmat Ulyaz

\section{Pendapatan}

Pendapatan Suku Tobelo Dalam dikategorikan menjadi beberapa kategori diantaranya tinggi, sedang dan rendah, Berdasarkan hasil penelitian, pendapatan Suku Tobelo Dalam masih digolongkan dalam kategori rendah ini dilihat dari pendapatan mereka kurang dari Rp500.000 (sebanyak 56,52\%) (Sagaf, 2018). Untuk kategori pendapatan tinggi yakni lebih dari Rp1.000.000 (sebanyak 6,52\%), sementara itu 50\% lainnya tergolong berpendapatan sedang. Tingkat pendapatan suku Togutil berhubungan erat dengan pekerjaan.

Jenis pekerjaan merupakan salah satu faktor yang mempengaruhi pendapatan seseorang (Maisaroh, 2017). Selain jenis pekerjaan, tingkat pendidikan merupakan faktor lain yang mempengaruhi pendapatan.

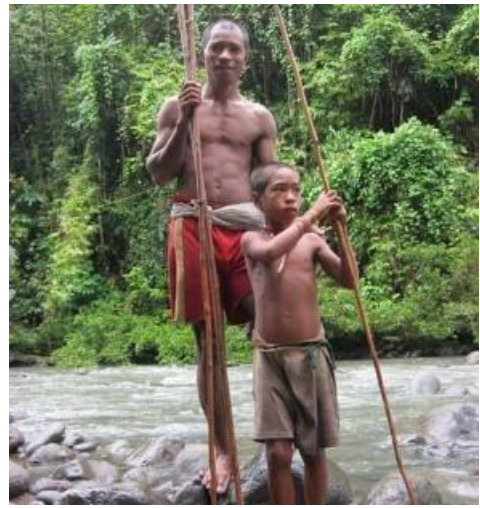

Gambar 5. Warga Suku Tobelo Dalam Bersama Anaknya Sedang Mencari Ikan Sumber: Opan Jacky 


\section{Nilai-Nilai Pancasila}

Nilai adalah sesuatu yang berharga bagi diri suatu individu, berguna dalam kehidupan, dan berfungsi sebagai pegangan hidup manusia sebagai harkat dan martabatnya. Nilai dapat diperoleh dari pengajaran, lingkungan sekitar, dan pedoman lainnya yang dianut manusia dan berdampak pada sikap dan perilaku hidup manusia (Rachman et al., 2021).

Pancasila dapat dimaknai sebagai dasar negara, falsafah, dan ideologi bangsa. Dengan ini Pancasila dapat digunakan sebagai acuan bagi warga negara Indonesia dalam pelaksanaan kehidupan bermasyarakat, berbangsa, dan bernegara secara nyata di kehidupan. Pancasila sebagai dasar negara memiliki arti Pancasila digunakan sebagai dasar ilmu dan sumber dari segala hukum yang berlaku di Indonesia serta berguna dalam pengaturan penyelenggaraan negara dalam pemerintahan dan penegakan hukum (Dewantara \& Nurgiansah, 2021b).

Pancasila sebagai falsafah atau pandangan hidup bangsa berarti nilai-nilai dari Pancasila berfungsi sebagai pedoman dan acuan dalam bersikap dan bertingkah laku dalam perbuatan sehari-hari dalam kehidupan sosial bermasyarakat, berbangsa, dan bernegara. Pancasila sebagai ideologi nasional berfungsi untuk mengarahkan bangsa Indonesia dalam perwujudan cita- cita nasional yang tertuang dalam pembukaan UUD 1945, yaitu merdeka, bersatu, berdaulat adil dan makmur (Dewantara \& Nurgiansah, 2021a).

Dengan pandangan Pancasila yang dianut maka semua ideologi, perkataan, perilaku, dan tindakan masyarakat dalam segala aspek kehidupan di masyarakat harus berlandaskan dari nilai-nilai Pancasila (Nurgiansah, 2020). Dalam pemahamannya nilai-nilai Pancasila dibagi menjadi tiga tingkatan yaitu: nilai dasar Pancasila, nilai instrumental Pancasila, dan nilai praksis Pancasila (Nurgiansah, 2021).

\section{Nilai Dasar Pancasila}

Nilai dasar adalah nilai yang bersifat tetap, tidak tergantikan oleh waktu, cenderung abstrak, diterima secara umum, berlaku di segala tempat. Kandungan dari nilai dasar Pancasila berupa pegangan dasar dan makna secara langsung dari setiap nilai yang terdapat dalam sila-sila Pancasila (Nurgiansah \& Al Muchtar, 2018).

Nilai dasar Pancasila terdapat dalam Pembukaan UUD 1945. Nilai dasar dari Pancasila adalah nilai ketuhanan, nilai kemanusiaan, nilai persatuan, nilai kerakyatan, dan nilai keadilan sosial. Nilai tersebut diperoleh dari masing-masing sila dalam Pancasila. Hal ini tertuang dalam Undang-Undang No.10 tahun 2004 Pasal 2 yang menyatakan bahwa Pancasila merupakan sumber dari segala sumber hukum negara.

\section{Nilai Instrumental Pancasila}

Nilai instrumental adalah nilai yang berguna sebagai pegangan dalam dari nilainilai dasar. Nilai dasar belum dapat bermakna sepenuhnya apabila nilai dasar tersebut belum memiliki parameter yang jelas dan konkrit tertuang dalam sebuah peraturan. Dapat ditarik kesimpulan bahwa nilai instrumental hakikatnya sebagai pengembangan dari nilai-nilai dasar. Dalam kehidupan bernegara, nilai instrumental didapatkan dari nilai-nilai yang berada di dalam sila Pancasila.

Perwujudan nilai instrumental Pancasila pada umumnya dapat ditemui dalam Undang-Undang Dasar 1945, Undang-Undang, Peraturan Pemerintah, dan segala peraturan lainnya seperti Peraturan Daerah. Nilai instrumental Pancasila juga dapat dilihat dalam normanorma yang berlaku di lingkungan bermasyarakat. Seperti norma adat, norma sosial, norma agama, norma asusila, dan 
lain-lain.

\section{Nilai Praksis Pancasila}

Nilai praksis adalah nilai yang merupakan penjabaran lebih lanjut atau pengembangan dari nilai dasar dan nilai instrumental dan diterapkan dalam kehidupan bermasyarakat yang nyata. Dengan demikian, nilai praksis Pancasila merupakan pelaksanaan di kehidupan bermasyarakat dari nilai-nilai dasar dan nilai- nilai instrumental. Nilai praksis hakikatnya berisi nilai-nilai dasar dan nilainilai instrumental sehingga tidak akan bertentangan isinya jika dibandingkan dengan nilai-nilai dasar dan nilai-nilai instrumental tersebut. Dalam penyelenggaraan nilai praksis pancasila, diperlukan pemahaman atas makna dari masing-masing sila Pancasila.

Mengutip dari Prof. Dr. Drs. Suranto, M.Pd., M.Si., didapatkan makna dari sila-sila Pancasila. Makna dari sila ke-1 Pancasila yang berbunyi "Ketuhanan Yang Maha Esa" adalah adanya pengakuan kausa prima atau sebab utama dalam kehidupan yaitu Tuhan Yang Maha Esa, negara harus menjamin keharusan penduduk Indonesia untuk memeluk agama sesuai dengan kepercayaannya masing- masing dan beribadah menurut agama yang dianut oleh setiap individu, penduduk dilarang menganut atheis di Indonesia, dan negara serta masyarakat saling mewujudkan toleransi dalam kehidupan beragama dan bermasyarakat.

Makna dari sila ke-2 Pancasila yang berbunyi "Kemanusiaan yang adil dan beradab" adalah penempatan setiap manusia sesuai dengan hakikat dirinya sebagai makhluk ciptaan tuhan, menjunjung tinggi kemerdekaan sebagai hak segala bangsa, dan mewujudkan keadilan dalam kehidupan serta membuat peradaban yang kuat.

Makna dari sila ke-3 Pancasila yang berbunyi "Persatuan Indonesia" adalah sikap nasionalisme, menumbuhkan cinta kepada bangsa dan tanah air, meningkatkan persatuan dan kesatuan bangsa, menghilangkan kekuatan dan kekuasaan yang berlebihan, dan menumbuhkan rasa senasib dan sepenanggungan antar masyarakat.

Makna dari sila ke-4 Pancasila yang berbunyi "Kerakyatan yang dipimpin oleh hikmat kebijaksanaan dalam permusyawaratan/perwakilan" adalah penerapan demokrasi, pengutamaan sikap anti kekerasan dalam penyelesaian masalah dan konflik di masyarakat, menggunakan musyawarah atau mufakat yang jujur dalam pengambilan keputusan, dan menumbuhkan sikap bijaksana dalam perbedaan dan dalam menghadapi sengketa.

Makna dari sila ke-5 Pancasila yang berbunyi "Keadilan sosial bagi seluruh rakyat Indonesia" adalah menjadikan kemakmuran yang merata bagi seluruh rakyat Indonesia serta pemanfaatan seluruh kekayaan alam secara bersama untuk kesejahteraan rakyat.

\section{Pembahasan}

Pada bagian ini, akan dijelaskan oleh penulis berbagai pengamalan nilai praksis masing-masing sila Pancasila dalam kehidupan sehari-hari masyarakat adat suku Tobelo Dalam.

\section{Pengamalan Nilai Praksis Sila ke-1 Pancasila}

Dalam Undang-Undang Dasar (UUD) 1945 Pasal 29 Ayat 1 dan 2 tentang Sila ke1: (1) Negara berdasarkan atas Ketuhanan Yang Maha Esa (2) Negara menjamin kemerdekaan tiap-tiap penduduk untuk memeluk agamanya masing- masing dan untuk beribadah menurut agama dan kepercayaannya itu.

Sebagian besar masyarakat suku Tobelo dalam masih menganut kepercayaan leluhur berupa penyembahan 
pada ruh, namun masyarakat suku Tobelo Dalam yang terletak dekat dengan penduduk luar sudah mulai meninggalkan kepercayaan leluhur tersebut sejak tahun 1970-an dan Sebagian besar menganut agama Kristen Protestan.

Penerapan Sila ke-1 pada suku Tobelo Dalam belum sepenuhnya diterapkan, karena masyarakatnya masih menganut kepercayaan AnimismeDinamisme yang keberadaannya belum diakui negara, namun dalam membina kerukunan hidup di antara masyarakat luar yang memiliki kepercayaan yang berbeda, suku tobelo dalam sudah terbuka dan banyak melakukan kerja sama dengan masyarakat luar. Di samping itu berdasarkan Pasal 28I ayat (1) UUD 1945 menjelaskan bahwa hak untuk beragama dan kepercayaan tertentu merupakan hak asasi manusia, yang selayaknya dilindungi oleh negara sesuai dengan yang tercantum di Pasal 29 ayat (2) UUD 1945 menjamin agar pemeluk agama dan peribadatan berjalan dengan baik.

\section{Pengamalan Nilai Praksis Sila ke-2 Pancasila}

Kehidupan manusia yang beradab dapat diwujudkan salah satunya dengan pendidikan karakter. Pendidikan karakter biasanya diajarkan pada jenjang SD, SMP, SMA. Data pendidikan terakhir masyarakat suku Tobelo Dalam yakni tidak sekolah sebanyak 20 kepala keluarga (43,5\%), SD 14 kepala keluarga (30.4\%), SMP 9 kepala keluarga $(19,6 \%)$, sedangkan SMA hanya 3 kepala keluarga (6,5\%). Hal ini sangat mengkhawatirkan mengingat pendidikan adalah investasi yang sangat penting demi kehidupan yang lebih baik dengan karakter yang beradab. Dari data ini dapat dibuat hipotesis bahwa suku Tobelo Dalam tidak memiliki karakter beradab karena hanya sedikit yang mengenyam pendidikan.

Namun pada praktiknya, didapatkan bahwa interaksi sosial di suku Tobelo
Dalam berjalan dengan sangat lancar, dilihat dari cara mereka saling membantu dalam berbagai hal untuk memenuhi kebutuhan hidup. Meski tertutup dengan dunia luar, interaksi sosial dengan masyarakat umum juga berjalan dengan baik berupa kerja sama. Dapat disimpulkan bahwa, meskipun banyak yang tidak mengenyam pendidikan, suku Tobelo Dalam masih memiliki nilai Pancasila, yaitu kemanusiaanyang beradab.

Kemudian, dalam adat Tobelo, setiap kelahiran bayi perempuan dirayakan dengan lima bibit pohon, sedangkan bayi laki-laki ditandai dengan 10 bibit pohon. Hal ini disebabkan laki-laki bertanggung jawab dalam mencari nafkah, sehingga harus menanam pohon lebih banyak. Meski demikian, hal tersebut terkesan menganggap derajat laki-laki lebih tinggi daripada perempuan dan hal ini merupakan suatu bentuk keadilan. Tidak disebutkan perilaku suku Tobelo yang lain yang mencerminkan ketidakadilan, namun tidak bisa disimpulkan juga bahwa suku Tobelo tidak menerapkan keadilan karena tradisi yang ada bersifat turun temurun yang berasal dari leluhur mereka.

\section{Pengamalan Nilai Praksis Sila ke-3 Pancasila}

Persatuan dan kesatuan di antara masyarakat suku Tobelo Dalam dalam kehidupan sehari-hari tentu terlihat dari interaksi sosial di kalangan masyarakat suku Tobelo Dalam yang berjalan dengan sangat baik, dilihat dari cara mereka yang menerapkan sistem gotong royong dan saling membantu dalam berbagai hal yang mampu memenuhi kebutuhan hidup mereka sehari-hari.

Tidak hanya itu, masyarakat suku Tobelo Dalam juga sudah mulai terbuka dengan masyarakat luar dengan baik dan sudah mulai kerja sama dengan pemerintah setempat, salah satu kegiatan kerja sama diantara mereka yang 
dikategorikan sebagai hal yang sudah mencerminkan keterbukaan masyarakat suku Tobelo Dalam untuk memajukan pergaulan demi persatuan dan kesatuan bangsa adalah dengan diterapkannya salah satu program pembinaan pemerintah setempat untuk suku togutil.

Program berupa Pembinaan Sosial Tempat Asal (PSTA) dan Pembinaan Sosial Tempat Baru (PSTB) yang baru diselenggarakan pemerintah untuk memperbaiki lingkungan hidup suku Tobelo Dalam yang keberadaannya terpencil, program ini juga membimbing dan memfasilitasi masyarakat Suku Tobelo dalam berupa perumahan tempat tinggal, dan membimbing mereka agar siap untuk menerima perubahan dan pembaharuan yang akan terjadi melalui sistem pemukiman sosial baru yang lebih layak, karena situasi tempat tinggal masyarakat Tobelo Dalam yang memprihatinkan dalam segi keamanan dalam berbagai bencana.

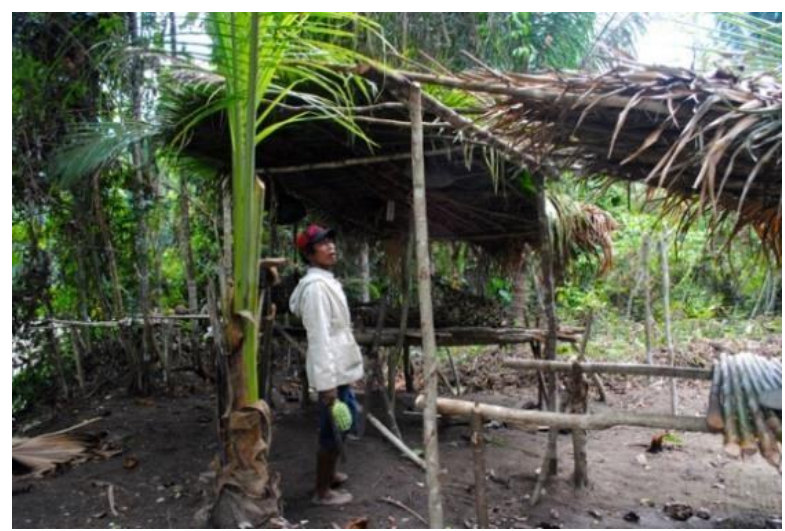

Gambar 6. Rumah Warga Tobelo Dalamyang Kosong karena Penghuni Sedang Berburu Sumber: M. Rahmat Ulyaz

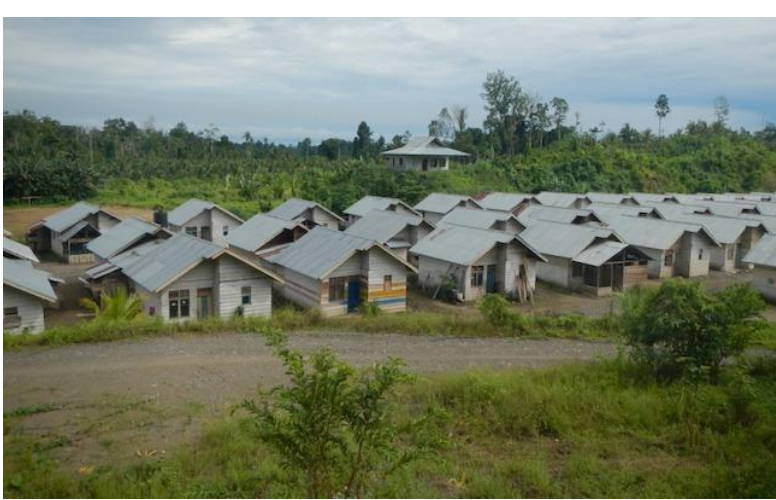

Gambar 7. Perumahan Komunitas Tobelo Dalam Melalui Program Pemda Halmahera Timur di Dusun Walaino Sumber: Supriyadi

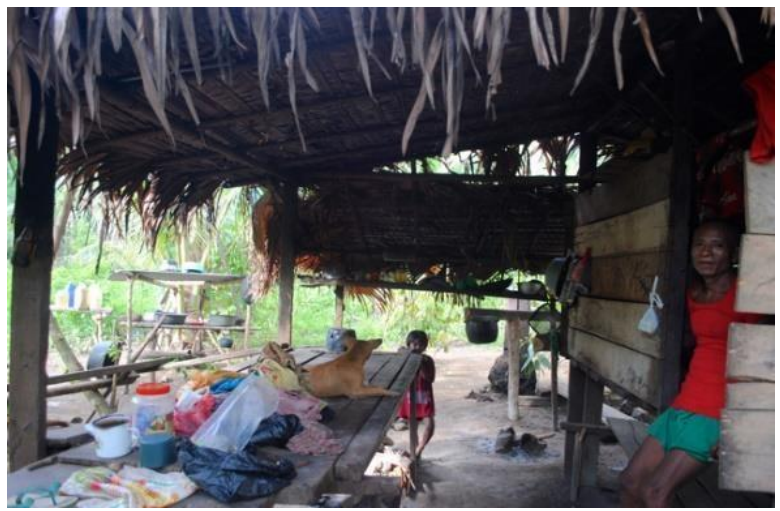

Gambar 8. Rumah Warga Tobelo Dalam yang Menetap di Hutan TayawiSumber: M. Rahmat Ulyaz

\section{Pengamalan Nilai Praksis Sila ke-4 Pancasila}

Suku Adat Tobelo Dalam merupakan salah satu bagian dari masyarakat adat Hibua Lamo. Dalam suku adat dan masyarakat adat tersebut terdapat berbagai sistem pemerintahan yang berjalan secara turun-temurun. Misalnya saja terdapat beberapa hoana (kampung) yang berperan mengatur kehidupan bermasyarakat anggota Suku Adat Tobelo Dalam. Selain itu, ada juga pemimpin tertinggi di dalam masyarakat adat ini yang dikenal dengan istilah Jiko Makolano (raja teluk) (Buladja\& Duma, 2017).

Jiko Makolano bukanlah jabatan yang berlaku secara turun- temurun dalam satu keluarga sebagaimana kerajaan, 
kesultanan, atau masyarakat adat lain yang pemimpinnya hanya berasal dari suatu keluarga atau keturunan tertentu. Jiko Makolano dipilih di antara warga yang sederajat sehingga tidak adanya sistem hierarki yang berlaku di masyarakat adat tersebut. Sistem pemilihannya pun sangat menjunjung tinggi nilai-nilai demokratis dan musyawarah sebab pemilihannya dilakukan melalui musyawarah besar di rumah adat yang dihadiri oleh seluruh pemangku adat yang ada. Selanjutnya, pemangku adat akan menentukan kriteria seorang Jiko Makolano yang sesuai melalui kesepakatan bersama dan memilih Jiko Makolano nya pun melalui musyawarah berdasarkan kriteria-kriteria yang telah dibuat sebelumnya.

Sistem pemerintahan yang dilakukan berdasarkan cara mufakat memang telah mereka terapkan sejak dahulu, sehingga keputusan yang dibuat cukup mewakilkan semua orang sebab dalam pengambilan keputusannya melibatkan banyak pihak. Berdasarkan uraian-uraian di atas, sistem pemerintahan yang berjalan di masyarakat Suku Tobelo Dalam menganut sistem-sistem yang universal dan tidak bertentangan dengan nilai-nilai Pancasila khususnya sila ke-4 karena sistem pemerintahan dan kemasyarakatannya sudah dilandasi oleh kebijaksanaan dalam pengambilan keputusan dan menggunakan cara musyawarah untuk mencapai mufakat dalam mengambil sebuah keputusan.

\section{Pengamalan Nilai Praksis Sila ke-5 Pancasila}

Implementasi keadilan sosial bagi seluruh masyarakat Indonesia yang sekarang dilakukan oleh masyarakat Suku Tobelo Dalam bidang pendidikan adalah dimulainya penyadaran atas pendidikan. Walaupun jenjang pendidikan yang dilaksanakan mayoritas masih sampai dengan jenjang Sekolah Dasar (SD) hal ini sudah cukup baik sebagai langkah awal pengembangan masyarakat Suku Tobelo Dalam.

Interaksi sosial antar masyarakat Suku Tobelo Dalam juga saling menunjang kemakmuran satu sama lain dengan contoh cara hidup yang saling bekerja sama bahkan saling bertukar makanan dan mencari bahan makanan yaitu sagu papeda bersama. Interaksi Suku Tobelo Dalam dengan alam yang memanfaatkan sumber hasil alam demi memenuhi kebutuhan masyarakat sambil melestarikan alam dengan menanam pohon juga mengamalkan makna nilai Pancasila ke-5 yaitu seluruh kekayaan alam dipergunakan bagi kesejahteraan rakyat.

Dapat disimpulkan bahwa secara garis besar masyarakat Suku Tobelo Dalam sudah cukup menjunjung keadilan sosial bagi masyarakatnya sendiri. Namun, bila ditinjau dari interaksi dengan masyarakat di luar Suku Tobelo Dalam apalagi dalam lingkup nasional maka Suku Tobelo Dalam harus diberi kesempatan lebih untuk mengembangkan pendidikannya serta kesempatan kerja yang lebih baik. Akan lebih baik jika pendidikan untuk Suku Tobelo Alam dititikberatkan pada pengembangan dan perlindungan alam sehingga dapat lebih sesuai dengan jati diri Suku Tobelo Dalam serta tidak mendegradasi kekayaan serta keunikan keberagaman bangsa Indonesia.

\section{KESIMPULAN}

Berdasarkan studi pustaka yang telah dilakukan, simpulan yang diperoleh adalah sebagai berikut: Beberapa cara yang dilakukan suku Tobelo Dalam untuk beradaptasi dengan lingkungan luar yang lebih modern dari mereka di antaranya serta mengenyam pendidikan minimal bangku sekolah dasar, meninggalkan kepercayaan lokal sejak tahun 1970-an dan beralih ke keyakinan yang ditetapkan Indonesia melalui Undang-Undang. Selain 
itu, masyarakat Tobelo Dalam yang menikah dengan pasangan yang berasal dari luar suku Tobelo Dalam sudah sering terjadi. Suku Tobelo Dalam bekerja sama dengan masyarakat luar untuk memenuhi kebutuhan kehidupan sehari-hari sehingga terjalin hubungan dan interaksi sosial yang baik dengan masyarakat luar yang lebih modern. Masyarakat suku Tobelo Dalam mulai berlatih untuk menerima perubahan dan pembaharuan yang terjadi melalui program Pembinaan Sosial Tempat Asal (PSTA) dan Pembinaan Sosial Tempat Baru (PSTB) pemukiman sosial baru yang digalakkan oleh pemerintah.

Interaksi sosial di kalangan masyarakat suku adat Tobelo Dalam berupa sistem gotong royong dan saling membantu menggambarkan bahwa sebagian besar dari Suku Tobelo Dalam sudah mengamalkan nilai-nilai praksis Pancasila sila ketiga. Sistem gotong royong dan saling membantu juga menggambarkan peradaban suku adat Tobelo Dalam yang sesuai dengan nilai praksis Pancasila sila kedua. Sistem pemerintahan dalam masyarakat suku adat Tobelo Dalam juga sudah sesuai dengan nilai-nilai Pancasila sila keempat sebab pemilihan pemimpin masyarakat suku adat Tobelo Dalam dilakukan secara musyawarah dengan menjunjung tinggi nilai-nilai demokratis. Hingga saat ini, hak pendidikan bagi masyarakat suku adat Tobelo Dalam sudah mulai dipenuhi. Tak hanya itu, dalam kehidupan sosialnya, masyarakat suku Adat Tobelo Dalam senantiasa menjaga alam dan memanfaatkannya untuk kepentingan dan kesejahteraan bersama. Atas dasar kedua hal tersebut, dapat dikatakan bahwa sebagian besar masyarakat suku adat Tobelo Dalam sudah cukup mengamalkan nilai-nilai praksis Pancasila sila kelima. Akan tetapi, dalam hal keyakinan, sebagian besar dari mereka masih menganut kepercayaan terhadap roh leluhur. Masih sedikit masyarakat Suku Tobelo Dalam yang menganut agama resmi sesuai dengan hukum Indonesia. Maka, masyarakat suku adat Tobelo Dalam belum cukup mengamalkan nilai-nilai praksis Pancasila sila pertama. Jadi, berdasarkan kajian pustaka yang telah dilakukan, simpulan yang diperoleh adalah sebagian besar masyarakat suku adat Tobelo Dalam secara tidak langsung sudah mengamalkan nilai-nilai praksis Pancasila dan hal tersebut sesuai dengan hipotesis awal yakni sebagian masyarakat suku adat Tobelo Dalam sudah mengamalkan nilainilai praksis Pancasila.

Beberapa kesulitan yang dialami masyarakat suku Tobelo Dalam untuk mengikuti perkembangan zaman di antaranya, kondisi geografis yang sulit dijangkau sehingga sulit untuk menerima perkembangan dan kemajuan modern dari masyarakat luar dan hambatan berupa jarak tempuh dan akses jalan yang buruk ke sekolah minat bersekolah anak-anak suku Tobelo Dalam cukup rendah.

Saran yang diajukan berkaitan dengan pengimplementasian nilai-nilai praksis Pancasila di masyarakat adat Suku Tobelo Dalam adalah perlu adanya jaminan dari pemerintah untuk menjaga kearifan lokal dan kekayaan sumber daya hayati di lingkungan masyarakat suku Tobelo Dalam sebab kehidupan mereka yang memang sangat bergantung pada alam.

Dengan adanya jaminan tersebut, mereka dapat terus memanfaatkannya untuk kepentingan kesejahteraan bersama sesuai nilai-nilai praksis sila kelima Pancasila yang sudah mereka terapkan dalam kehidupan sehari-hari. Selain itu, upaya-upaya penyebaran agama kepada masyarakat suku Tobelo Dalam tidak boleh dengan paksaan terlebih lagi kekerasan. Langkah yang seharusnya diambil baik oleh pemerintah maupun masyarakat sekitar daerah tersebut adalah menghargai dan menghormati keyakinan mereka sebab 
saling menghargai, menghormati, dan toleransi merupakan pengamalan nilai praksis Pancasila sila pertama yang harus dijunjung tinggi oleh seluruh elemen masyarakat.

\section{DAFTAR PUSTAKA}

Bella, R., Gujali, A. I., Dewi, R. S., Lion, E., \& Maryam, M. (2021). Sistem Masyarakat dan Organisasi Suku Dayak Ngaju (Studi Kasus di Desa Mandomai Kalimantan Tengah). Jurnal Kewarganegaraan, 5(2), 364-375.

Buladja, \& Duma, R. (2017). Peran Nilai Adat 'Hibua Lamo' dalam Upaya Merekonsiliasi Masyarakat Pasca Perpecahan Jemaat: Studi Sosiologis Masyarakat Desa Duma dan Desa Mamuya, Kabupaten Halmahera Utara. Salatiga: Program Studi Sosiologi FISKOMUKSW.

Chilwanto, E., Safna, S., Mutiara, M., Rahmad, G., Offeny, O., \& Saefulloh, A. (2021). Upacara Mamapas Lewu (Studi Kasus di Kota Kasongan Kalimantan Tengah). Jurnal Kewarganegaraan, $5(2)$,

374-354. https://journal.upy.ac.id/index.php/pkn/article/view/1673/pdf

Dewantara, J. A., \& Nurgiansah, T. H. (2021a). Peningkatan Keaktifan Belajar Melalui Penerapan Model Picture And Picture Dalam Pembelajaran PPKn di Sekolah Dasar. Jurnal Publikasi Pendidikan, 11(3), 234-241.

Dewantara, J. A., \& Nurgiansah, T. H. (2021b). Strengthening Pancasila Values During the Covid-19 Pandemic. Edukatif: Jurnal Ilmu Pendidikan, 3(4), 2411-2417.

Dewi Sarah, S., Julita, S., Yowisa Yolanda, P., Nurtia Indah, S., Risa, S., \& Yohana, M. (2021). Peranan Pemerintah Desa dalam Pembangunan Infrastruktur. Jurnal Kewarganegaraan, 5(2), 295-302. https://doi.org/10.26418/j-psh.v12i1.46323

Duncan, C. R. (2009). Reconciliation and Revitalization: The Resurgence of Tradition in Postconflict Tobelo, North Maluku, Eastern Indonesia. TheJournal of Asian Studies.

Febriyanti, N., \& Dewi, D. A. (2021). Pengembangan Nilai Moral Peserta Didik dalam Pembelajaran Pendidikan Kewarganegaraan. Jurnal Kewarganegaraan, 5(2), 476-482. https://journal.upy.ac.id/index.php/pkn/article/view/1772

Hikmah, S. N., \& Dewi, D. A. (2021). Meninjau Sejauh Mana Implementasi Nilai Pendidikan Karakter Melalui Pendidikan Kewarganegaraan di Perguruan Tinggi. Jurnal

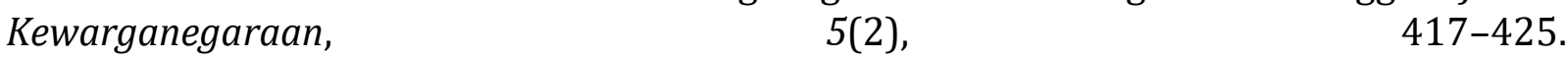
https://journal.upy.ac.id/index.php/pkn/article/view/1745

Isnaini, P. N., \& Dewi, D. A. (2021). Upaya Menerapkan Nilai-Nilai Pancasila Di Masa Pandemi $\begin{array}{llr}\text { Covid-. Jurnal Kewarganegaraan, } & \text { 52), }\end{array}$ https://journal.upy.ac.id/index.php/pkn/article/view/1344

Koentjaraningrat. (2003). Pengantar Antropologi I. Jakarta: PT Rineka Cipta. Maisaroh, N. (2017). Analisis Pengaruh Tingkat Pendapatan terhadap Kualitas Hidup di Kecamatan Medan Perjuangan Kota Medan.

Martodirdjo, H. S. (1996). A Changing Tugutil of Halmahera, Indonesia: Twofold Studies for Further Research.

Nazir, M. (1988). Metode Studi Pustaka dalam Metode Penelitian.

Nurgiansah, T. H. (2018). Pengembangan Kesadaran Hukum Berlalu Lintas Siswa Melalui Model Pembelajaran Jurisprudensial Dalam Pendidikan Kewarganegaraan (Studi Kasus di SMK Bina Essa Kabupaten Bandung Barat Kelas X Administrasi Perkantoran). Tesis. Repository Universitas Pendidikan Indonesia, Oktober. http://ieeeauthorcenter.ieee.org/wp-content/uploads/IEEE-Reference- 
Guide.pdf\%0Ahttp://wwwlib.murdoch.edu.au/find/citation/iee.html\%0Ahttps://doi.or g/10.1016/j.cie.2019.07.022\%0Ahttps://github.com/ethereum/wiki/wiki/White-

Paper\%0Ahttps://tore.tuhh.de/hand

Nurgiansah, T. H. (2020). Filsafat Pendidikan. In Banyumas: CV Pena Persada.

Nurgiansah, T. H. (2021). Pendidikan Pancasila. In Solok: CV Mitra Cendekia Media.

Nurgiansah, T. H., \& Al Muchtar, S. (2018). Development of Student Awareness through Student Learning Model Jurisprudential in Citizenship Education. ATLANTIS PRESS, 251(Acec), 670-674. https://doi.org/10.2991/acec-18.2018.150

Pertiwi, S. G., \& Hidayah, Y. (2021). Implementasi Pendidikan Hak Asasi Manusia dalam Dunia Pendidikan Sekolah Dasar. Jurnal Kewarganegaraan, 5(2), 376-380. https://journal.upy.ac.id/index.php/pkn/article/view/1717

Prasetyo, W. E. (2013). Hubungan antara Tingkat Pendapatan dan Pengeluaran PanganNonpangan Keluarga dengan Status Gizi Anak Prasekolah di Kelurahan Semanggi dan Sangkrah, Kecamatan Pasar Kliwon, Surakarta.

Rachman, F., Ryan, T., Kabatiah, M., Batubara, A., Pratama, F. F., \& Nurgiansah, T. H. (2021). Pelaksanaan Kurikulum PPKn pada Kondisi Khusus Pandemi Covid-19. Jurnal Basicedu, 5(6), 5682-5691.

Raharja, P., \& Mandala, M. (2005). Teori Ekonomi Makro. Jakarta: Fakultas Ekonomi Universitas Indonesia.

Sabar, S. (2015). Pengantar Antropologi: Integrasi Ilmu dan Agama.

Sagaf, S. (2018). Perspektif Fenomenologi Kehidupan Sosial Ekonomi dan Bentuk Pembinaan Suku Togutil Kabupaten Halmahera Timur.

Setiawan, S. (2021, September 16). GURUPENDIDIKAN.COM. Retrieved from Sejarah Suku Togutil: https://www.gurupendidikan.co.id/suku-togutil/

Setyawati, Y., Septiani, Q., Aulia Ningrum, R., \& Hidayah, R. (2021). Imbas Negatif Globalisasi terhadap Pendidikan di Indonesia. Jurnal Kewarganegaraan, 5(2), 306-315. https://docplayer.info/214608960-Imbas-negatif-globalisasi-terhadap-pendidikan-diindonesia.html

Sofiyatul, N., \& Dewi, A. (2021). SKKP BAWASLU Sebagai Sarana Pendidikan Politik dalam Upaya meningkatkan Partisipasi Politik Warga Negara. Jurnal Kewarganegaraan, 5(2), 355-363.

Sosebeko, T. S. (2010). Asal Usul Suku Togutil di Bumi Halmahera. 10. Sosebeko, T. S. (2021, Oktober 26). Asal Usul Suku Togutil di Bumi Halmahera. Retrieved from http://www.halmaherautara.com/bdy/asal-usul-suku-togutil-di-halmahera.html

Susanty, H. (2015). Fungsi Ikatan Persaudaraan Muslim Socfindo (IPMS) dalam Membangun Hubungan Sosial dengan Masyarakat Sekitar. Perspektif Sosiologi, 1.

Ulfah, N., Hidayah, Y., \& Trihastuti, M. (2021). Urgensi Etika Demokrasi di Era Global: Membangun Etika dalam Mengemukakan Pendapat bagi Masyarakat Akademis Melalui Pendidikan Kewarganegaraan. Jurnal Kewarganegaraan, 5(2), 329-346. https://journal.upy.ac.id/index.php/pkn/article/view/1576

Ulhaz, M. R. (2017, Februari 3). MONGABAY. Retrieved from Suku Tobelo Dalam, Para Penjaga Hutan Tayawi (Bagian 1): https://www.mongabay.co.id/2017/02/03/suku-tobelodalam-para-penjaga-hutan-tayawi-bagian-1/

Yulia. (2016). Buku Ajar Hukum Adat. Sulawesi: Unimal Press Kampus Bukit Indah Lhokseumawe. 